Prepared in cooperation with Colorado Springs City Engineering

\title{
Temporal Change in Biological Community Structure in the Fountain Creek Basin, Colorado, 2001-2008
}

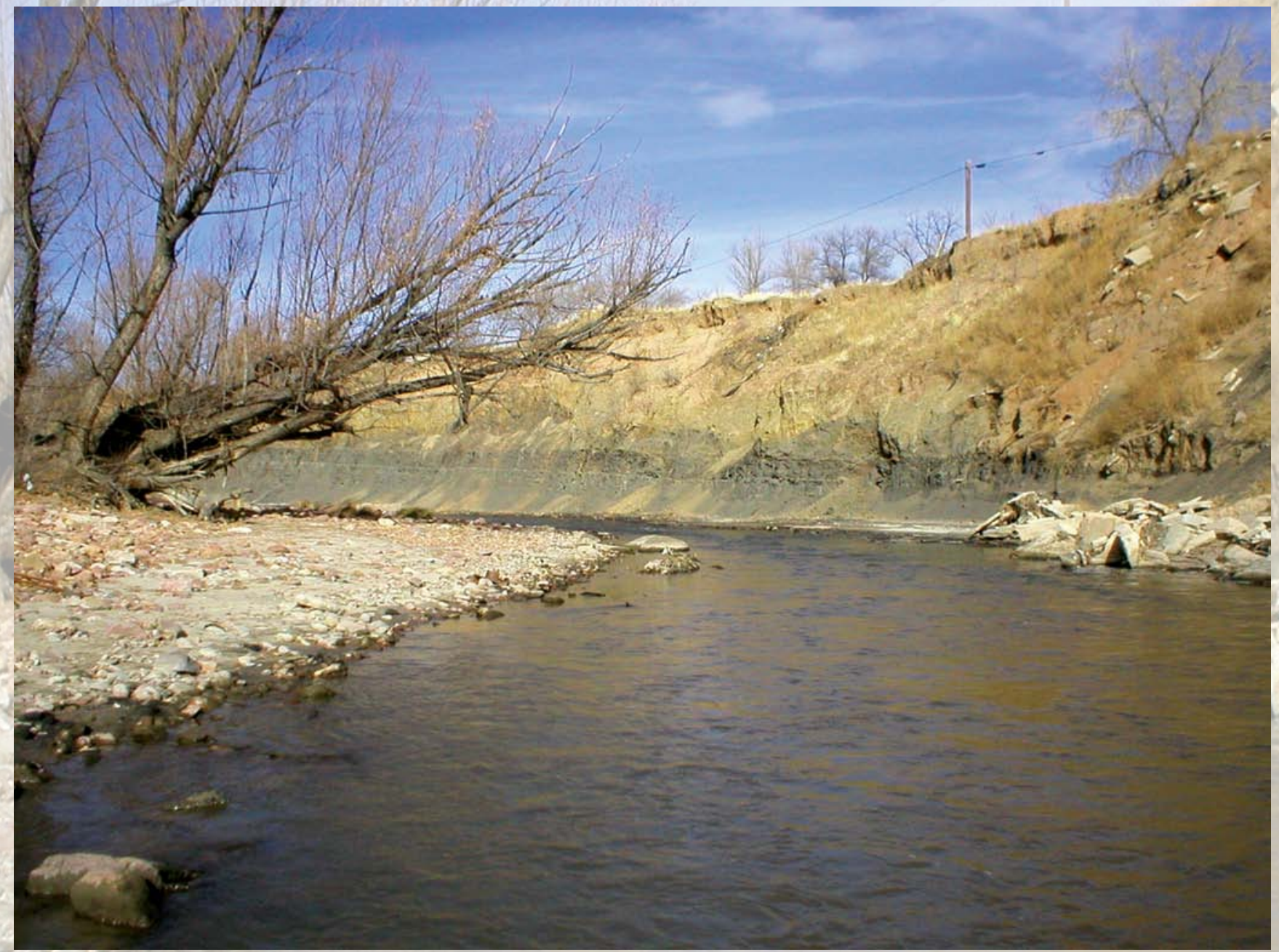

Scientific Investigations Report 2010-5103 
Photo on cover: Upper end of sampling reach looking upstream, Fountain Creek at Security, Colorado (07105800). Photo by Erin E. Evans, November 2007. 


\section{Temporal Change in Biological Community Structure in the Fountain Creek Basin, Colorado, 2001-2008}

By Robert E. Zuellig, James F. Bruce, and Robert W. Stogner

Prepared in cooperation with Colorado Springs City Engineering

Scientific Investigations Report 2010-5103 


\title{
U.S. Department of the Interior \\ KEN SALAZAR, Secretary \\ U.S. Geological Survey \\ Marcia K. McNutt, Director
}

\section{U.S. Geological Survey, Reston, Virginia: 2010}

\author{
For more information on the USGS - the Federal source for science about the Earth, its natural and living resources, \\ natural hazards, and the environment, visit http://www.usgs.gov or call 1-888-ASK-USGS \\ For an overview of USGS information products, including maps, imagery, and publications, \\ visit http://www.usgs.gov/pubprod \\ To order this and other USGS information products, visit http://store.usgs.gov
}

Any use of trade, product, or firm names is for descriptive purposes only and does not imply endorsement by the U.S. Government.

Although this report is in the public domain, permission must be secured from the individual copyright owners to reproduce any copyrighted materials contained within this report.

Suggested citation:

Zuellig, R.E., Bruce, J.F., and Stogner, R.W., 2010, Temporal change in biological community structure in the Fountain Creek basin, Colorado, 2001-2008: U.S. Geological Survey Scientific Investigations Report 2010-5103, 19 p. 


\section{Contents}

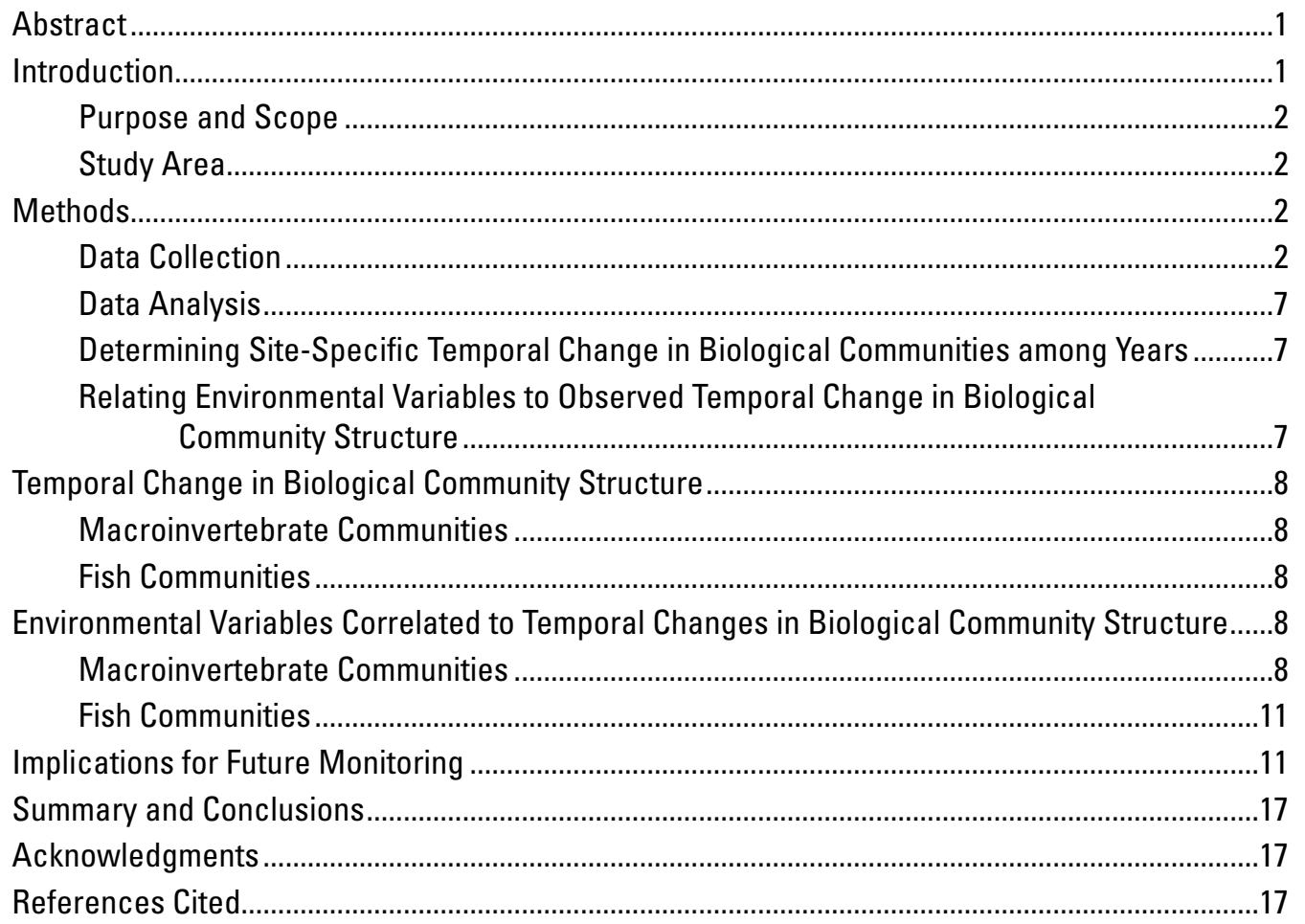

\section{Figures}

1. Map showing locations of sampling sites in the Fountain Creek basin,

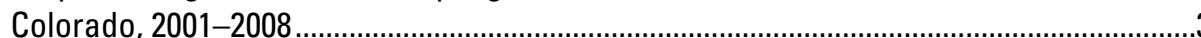

2. Spatial distribution of sites with and without temporal changes in macroinvertebrate communities among years in the Fountain Creek basin, Colorado, 2001-2008

3. Spatial distribution of sites with and without temporal changes in fish communities among years in the Fountain Creek basin, Colorado, 2003-2008

4. Spatial distribution of sites with and without temporal changes in fish (2003-2008) and macroinvertebrate (2001-2008) communities among years in the Fountain Creek basin, Colorado 


\section{Tables}

1. Description of sites and period of record for types of data collected in the Fountain Creek basin, Colorado, 2001-2008

2. Habitat, streamflow, and water-chemistry variables used to relate site-specific temporal patterns (seriation) in biological community structure, Fountain Creek basin, Colorado, 2001-2008

3. Correlation coefficients, percent significance level, and the number of years associated with the strength of multivariate seriation of macroinvertebrate communtiy structure among years (RELATE test for seriation)

4. Correlation coefficients and percent significance level associated with the strength of multivariate seriation of fish community structure among years (RELATE test for seriation).

5. Results of the BIO-ENV procedure determining which environmental variables best described observed multivariate temporal change (seriation) in macroinvertebrate community structure in the Fountain Creek basin, 2001-2008 .....13

6. Results of the BIO-ENV procedure determining which environmental variables best described observed multivariate temporal change (serial) in fish community structure in the Fountain Creek basin, 2003-2008 


\section{Conversion Factors}

Inch/Pound to SI

\begin{tabular}{|c|c|c|}
\hline Multiply & By & To obtain \\
\hline \multicolumn{3}{|c|}{ Length } \\
\hline inch (in) & $2.54 \times 10^{0}$ & centimeter $(\mathrm{cm})$ \\
\hline inch (in) & $2.54 \times 10^{1}$ & millimeter $(\mathrm{mm})$ \\
\hline inch (in) & $2.54 \times 10^{4}$ & micrometer $(\mu \mathrm{m})$ \\
\hline foot $(\mathrm{ft})$ & $3.048 \times 10^{-1}$ & meter $(\mathrm{m})$ \\
\hline mile (mi) & $1.609 \times 10^{0}$ & kilometer $(\mathrm{km})$ \\
\hline micrometer $(\mu \mathrm{m})$ & $1.0 \times 10^{2}$ & centimeter $(\mathrm{cm})$ \\
\hline \multicolumn{3}{|c|}{ Flow Rate } \\
\hline cubic foot per second $\left(\mathrm{ft}^{3} / \mathrm{s}\right)$ & $2.832 \times 10^{-2} 2.590$ & cubic meter per second $\left(\mathrm{m}^{3} / \mathrm{s}\right)$ \\
\hline \multicolumn{3}{|c|}{ Volume } \\
\hline milliliter $(\mathrm{ml})$ & 473.176 & pint (pt) \\
\hline
\end{tabular}

Temperature in degrees Celsius $\left({ }^{\circ} \mathrm{C}\right)$ may be converted to degrees Fahrenheit $\left({ }^{\circ} \mathrm{F}\right)$ as follows:

$$
{ }^{\circ} \mathrm{F}=\left(1.8 x^{\circ} \mathrm{C}\right)+32
$$

Vertical coordinate information is referenced to the North American Vertical Datum of 1988 (NAVD 88).

Horizontal coordinate information is referenced to the North American Datum of 1983 (NAD 83).

Altitude, as used in this report, refers to distance above the vertical datum.

Specific conductance is given in microsiemens per centimeter at 25 degrees Celsius $(\mu \mathrm{S} / \mathrm{cm}$ at $\left.25^{\circ} \mathrm{C}\right)$.

Concentrations of chemical constituents in water are given either in milligrams per liter (mg/L) or micrograms per liter $(\mu \mathrm{g} / \mathrm{L})$.

\section{Abbreviations}

BIO-ENV exploratory multivariate analysis linking biology to environmental variables

CDOW Colorado Division of Wildlife

CDPHE Colorado Department of Public Health and Environment

DC direct current

HIT Hydrologic Index Tool

MDS nonmetric multidimensional scaling

NWIS National Water Information System

NWQL National Water Quality Laboratory

PRIMER Plymouth Routines in Multivariate Ecological Research

QA/QC quality assurance/quality control

QMH qualitative multihabitat

RELATE nonparametric multivariate hypothesis test between two distance matrices

USGS U.S. Geological Survey 



\title{
Temporal Change in Biological Community Structure in the Fountain Creek Basin, Colorado, 2001-2008
}

\author{
By Robert E. Zuellig, James F. Bruce, and Robert W. Stogner
}

\section{Abstract}

In 2001, the U.S. Geological Survey, in cooperation with Colorado Springs City Engineering, began a study to better understand the relations between environmental characteristics and biological communities in the Fountain Creek basin in order to aide water-resource management and guide future monitoring activities. To accomplish this task, environmental (streamflow, habitat, and water chemistry) and biological (fish and macroinvertebrate) data were collected annually at 24 sites over a 6- or 8-year period (fish, 2003 to 2008; macroinvertebrates, 2001 to 2008). For this report, these data were first analyzed to determine the presence of temporal change in macroinvertebrate and fish community structure among years using nonparametric multivariate statistics. Where temporal change in the biological communities was found, these data were further analyzed using additional nonparametric multivariate techniques to determine which subset of selected streamflow, habitat, or water-chemistry variables best described site-specific changes in community structure relative to a gradient of urbanization.

This study identified significant directional patterns of temporal change in macroinvertebrate and fish community structure at 15 of 24 sites in the Fountain Creek basin. At four of these sites, changes in environmental variables were significantly correlated with the concurrent temporal change identified in macroinvertebrate and fish community structure (Monument Creek above Woodmen Road at Colorado Springs, Colo.; Monument Creek at Bijou Street at Colorado Springs, Colo.; Bear Creek near Colorado Springs, Colo.; Fountain Creek at Security, Colo.). Combinations of environmental variables describing directional temporal change in the biota appeared to be site specific as no single variable dominated the results; however, substrate composition variables (percent substrate composition composed of sand, gravel, or cobble) collectively were present in 80 percent of the environmental variable subsets that were significantly correlated with temporal change in the macroinvertebrate and fish community structure. Other important environmental variables related to temporal change in the biological community structure included those describing channel form (streambank height) and streamflow (normalized annual mean daily flow, high flood-pulse count).
Site-specific results from this study were derived from a relatively small number of observations (6 or 8 years of data); therefore, additional years of data may reveal other sites with temporal change in biological community structure, or could define stronger and more consistent linkages between environmental variables and observed temporal change. Likewise current variable subsets could become weaker. Nonetheless, there were several sites where temporal change was detected in this study that could not be explained by the available environmental variables studied herein. Modification of current data-collection activities may be necessary to better understand site-specific temporal relations between biological communities and environmental variables.

\section{Introduction}

Fountain and Monument Creeks (hereafter, Fountain Creek basin) drain approximately $926 \mathrm{mi}^{2}$ of the eastern slope of the Rocky Mountains in south-central Colorado. Several environmental factors that influence stream communities have been altered throughout Fountain Creek basin (for example, habitat alteration and riparian disturbance), which began in the mid-1800s. Several studies of Fountain Creek basin have described patterns in surface-water hydrology (Edelmann and others, 2002; Stogner, 2000), water chemistry (Mau and others, 2007), and sediment transport (von Guerard, 1989), and other studies have related some of these characteristics to urbanization and biological communities (Zuellig and others, 2007). Continued alteration of environmental factors is expected in the future as human population grows, especially in regards to surface-water hydrology, which could further influence water quality, in-stream habitat, and ultimately, biological communities.

Local, State, and Federal agencies are interested in better understanding the relations between environmental characteristics and biological communities in the Fountain Creek basin in order to aid water-resource management and guide future monitoring activities. In response to these needs, the U.S. Geological Survey (USGS), in cooperation with Colorado Springs City Engineering, began an evaluation of available biological (fish and macroinvertebrates) and associated environmental (streamflow, habitat, and water chemistry) data 
collected in the Fountain Creek basin between 2001 and 2008. These data were analyzed to determine the presence of multivariate serial change (hereafter, temporal change) in biological community structure. Where temporal change was found, the analysis was extended to determine which subset of available environmental variables best described observed temporal changes in biological communities. Results are intended to help water-resource management make informed decisions and guide future monitoring activities.

\section{Purpose and Scope}

This report describes temporal change in biological community structure in the Fountain Creek basin. A compilation of 180 macroinvertebrate and 64 fish community samples collected annually for 6 or 8 years from as many as 24 sites between 2001 and 2008 in the Fountain Creek basin is presented. Nine environmental variables (including characteristics of streamflow, habitat, and water chemistry) concurrently collected with the biological data were also compiled. Using various combinations of these data, the objectives were to (1) determine site-specific temporal changes in fish and macroinvertebrate community structure among years; (2) where temporal change was detected, determine if changes in aquatic communities were related to changes in selected environmental variables such as stream hydrology, habitat, or water-chemistry; and (3) discuss results in the context of long-term biological monitoring of the Fountain Creek basin. Habitat, fish, and macroinvertebrate data evaluated in this report are available upon request from the USGS Colorado Water Science Center (James Bruce, written commun., 2010). Stream-discharge (streamflow) and water-chemistry data can be obtained online at http://waterdata.usgs.gov/co/nwis (search by USGS station number; see table 1).

\section{Study Area}

The Fountain Creek basin encompasses approximately $926 \mathrm{mi}^{2}$ in south-central Colorado draining the eastern slope of the Rocky Mountains (fig. 1). Altitude ranges from 4,700 ft at the confluence with the Arkansas River to $14,109 \mathrm{ft}$ at the summit of Pikes Peak (source). Fountain and Monument Creeks are the two main drainages and are located in the transition of two distinctive physiographic landforms - the Front Range and the Colorado Piedmont (Hansen and Crosby, 1982) — which corresponds to two Level III ecoregions: the Southern Rockies and the Southwestern Tablelands (Omernik, 1987). The Front Range, which comprises the western onethird of the study area, is underlain by granite. Soils in this area are well drained and occur on steep slopes (Larsen, 1981; von Guerard, 1989). The Colorado Piedmont, which comprises the remaining eastern two-thirds of the area, abuts the base of the Rampart Range and is underlain by sandstone, shale, alluvial, and windlain deposits. Soils in this area are generally sandy and well drained with more gentle slopes
(Larsen, 1981; von Guerard, 1989). The soils and geology on the Colorado Piedmont are readily erodible. More details of the soils and geology of the study area can be found in Larsen (1981) and von Guerard (1989). See Mau and others (2007) and Edelman and others (2002) for a more detailed description of the study area. Also, Zuellig and others (2007) provide a historical perspective of present-day fish and macroinvertebrate communities.

\section{Methods}

Environmental (streamflow, habitat, and selected water chemistry) and macroinvertebrate data were collected annually at 15 sites from 2001 to 2008 and at an additional 9 sites between 2003 and 2008 (table 1, fig. 1). Fish data were collected annually at 10 sites between 2003 and 2008 and at one site between 2007 and 2008. Macroinvertebrate and fish data were analyzed for the presence of temporal change in community structure among years using nonparametric multivariate statistics (RELATE, PRIMER ver. 6.1, Plymouth, United Kingdom). Where temporal change was found, the data were further analyzed using additional multivariate techniques to determine which subset of streamflow, habitat, or waterchemistry variables best described site-specific changes in biological community structure (BIO-ENV, PRIMER ver 6.1, Plymouth, United Kingdom). Discussions of findings are focused to help direct future monitoring efforts and needed ecological investigations in the Fountain Creek basin.

\section{Data Collection}

Available streamflow, habitat, and water-chemistry characteristics as well as macroinvertebrate and fish community structure were quantified at 24 sites (table 1). The list of environmental variables chosen for study was, in part, selected from the findings of Zuellig and others (2007) where they presented a list of strongly correlated variables (Spearman's rho $>0.60, p<0.05)$ with impervious surface coverage in the Fountain Creek basin. The variables selected for study included percent of the stream reach composed of riffle habitat (pctRIF), bank height (BANKHT), Froude number (FROUDE), percent sand (pctSAND), percent gravel (pctGRAVEL), percent cobble (pctCOBB), normalized maximum daily mean flow (MH20), high flood-pulse count (FH1), and dissolved nitrate plus nitrite (DNO23) (table 2). Methods used to collect the data addressed in this report are briefly described in the sections below. See Zuellig and others (2007), Mau and others (2007), and the citations within those two reports for further explanation.

Hydrology. Instantaneous stream discharge (in $\mathrm{ft}^{3} / \mathrm{s}$ ) and computation of mean daily discharge $\left(\right.$ in $\mathrm{ft}^{3} / \mathrm{s}$ ) were measured and computed in accordance with standard USGS procedures described by Rantz and others (1982). Measurements of instantaneous stream discharge were made throughout the 


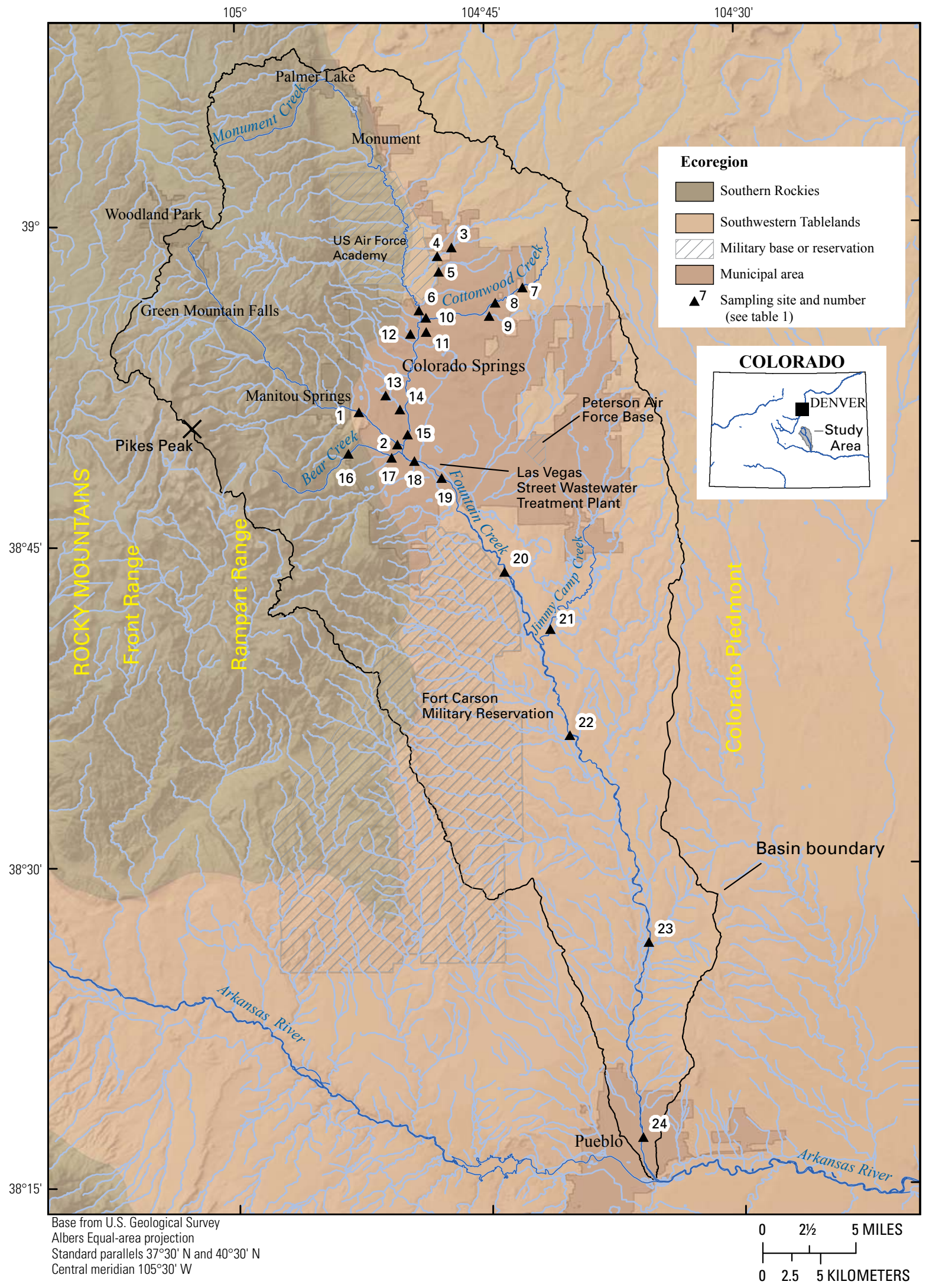

Figure 1. Locations of sampling sites in the Fountain Creek basin, Colorado, 2001-2008. 
Table 1. Description of sites and period of record for types of data collected in the Fountain Creek basin, Colorado, 2001-2008.

[USGS, U.S. Geological Survey; ID, identification; NAVD 88, North American Vertical Datum of 1988; ft, feet; mi² $^{2}$ square miles; X, collected; --, not collected]

\begin{tabular}{|c|c|c|c|c|c|c|c|c|c|}
\hline $\begin{array}{l}\text { Site } \\
\text { ID }^{1}\end{array}$ & $\begin{array}{l}\text { USGS } \\
\text { station } \\
\text { number }\end{array}$ & $\begin{array}{l}\text { Station } \\
\text { name }\end{array}$ & $\begin{array}{l}\text { Elevation } \\
\text { NAVD } 88 \\
\text { (ft) }\end{array}$ & $\begin{array}{l}\text { Drainage } \\
\text { area } \\
\left(\mathrm{mi}^{2}\right)\end{array}$ & $\begin{array}{l}\text { Streamflow } \\
\text { discharge }\end{array}$ & Chemistry & Habitat & Fish $^{2}$ & $\begin{array}{c}\text { Macro- } \\
\text { invertebrate }\end{array}$ \\
\hline 1 & 07103700 & $\begin{array}{l}\text { Fountain Creek near Colorado } \\
\text { Springs, Colo. }\end{array}$ & 6,110 & 103 & $\mathrm{X}$ & $\mathrm{X}$ & 2001-2008 & 2003-2008 & 2001-2008 \\
\hline 2 & 07103707 & $\begin{array}{l}\text { Fountain Creek below } 8 \text { th Street at } \\
\text { Colorado Springs, Colo. }\end{array}$ & 6,000 & 119 & -- & $\mathrm{X}$ & $2001-2008$ & 2003-2008 & 2001-2008 \\
\hline 3 & 385854104470100 & $\begin{array}{l}\text { Kettle Creek above Old Ranch Road } \\
\text { near Colorado Springs, Colo. }\end{array}$ & 6,670 & 15.46 & $\mathrm{X}$ & $\mathrm{X}$ & $2003-2008$ & -- & 2003-2008 \\
\hline 4 & 07103960 & $\begin{array}{l}\text { Kettle Creek above U.S. Air Force } \\
\text { Academy, Colo. }\end{array}$ & 6,620 & 16 & $\mathrm{X}$ & $\mathrm{X}$ & $2003-2008$ & -- & 2003-2008 \\
\hline 5 & 385750104475001 & $\begin{array}{l}\text { Pine Creek above Highway } 83 \text { at } \\
\text { Colorado Springs, Colo. }\end{array}$ & 6,540 & 3.67 & $\mathrm{X}$ & $\mathrm{X}$ & $2003-2008$ & -- & $2003-2008$ \\
\hline 6 & 07103970 & $\begin{array}{l}\text { Monument Creek above Woodmen } \\
\text { Road at Colorado Springs, Colo. }\end{array}$ & 6,270 & 181 & $\mathrm{X}$ & $\mathrm{X}$ & $2001-2008$ & 2003-2008 & 2001-2008 \\
\hline 7 & 07103977 & $\begin{array}{l}\text { Cottonwood Creek at Cowpoke } \\
\text { Road at Colorado Springs, Colo. }\end{array}$ & 6,875 & 5.93 & $\mathrm{X}$ & $\mathrm{X}$ & $2001-2008$ & -- & $2001-2008$ \\
\hline 8 & 07103980 & $\begin{array}{l}\text { Cottonwood Creek at Woodmen } \\
\text { Road near Colorado Springs, } \\
\text { Colo. }\end{array}$ & 6,680 & 10.3 & $\mathrm{X}$ & $\mathrm{X}$ & $2001-2008$ & -- & 2001-2008 \\
\hline 9 & 07103985 & $\begin{array}{l}\text { Cottonwood Creek Tributary above } \\
\text { Rangewood Drive at Colorado } \\
\text { Springs, Colo. }\end{array}$ & 6,630 & 2.81 & $\mathrm{X}$ & $\mathrm{X}$ & $2001-2008$ & -- & 2001-2008 \\
\hline 10 & 07103990 & $\begin{array}{l}\text { Cottonwood Creek at mouth at } \\
\text { Pikeview, Colo. }\end{array}$ & 6,265 & 18.7 & $\mathrm{X}$ & $\mathrm{X}$ & $2001-2008$ & -- & 2001-2008 \\
\hline 11 & 385501104483701 & $\begin{array}{l}\text { Monument Creek Tributary } 1 \text { near } \\
\text { Pulpit Rock at Colorado Springs, } \\
\text { Colo. }\end{array}$ & 6,255 & 0.697 & -- & $\mathrm{X}$ & $2003-2008$ & -- & 2003-2008 \\
\hline 12 & 07104050 & $\begin{array}{l}\text { North Rockrimmon Creek above } \\
\text { Delmonico Drive at Colorado } \\
\text { Springs, Colo. }\end{array}$ & 6,220 & 1.82 & $\mathrm{X}$ & $\mathrm{X}$ & $2001-2008$ & -- & $2003-2008$ \\
\hline 13 & 385204104510101 & $\begin{array}{l}\text { Monument Creek Tributary } 2 \text { below } \\
\text { Fillmore Street at Colorado } \\
\text { Springs, Colo. }\end{array}$ & 6,270 & 0.75 & $\mathrm{X}$ & $\mathrm{X}$ & $2003-2008$ & -- & 2003-2008 \\
\hline 14 & 385124104501301 & $\begin{array}{l}\text { Monument Creek Tributary } 2 \text { at } \\
\text { Sondermann Park at Colorado } \\
\text { Springs, Colo. }\end{array}$ & 6,060 & 2.04 & $\mathrm{X}$ & $\mathrm{X}$ & $2003-2008$ & -- & 2003-2008 \\
\hline 15 & 07104905 & $\begin{array}{l}\text { Monument Creek at Bijou Street at } \\
\text { Colorado Springs, Colo. }\end{array}$ & 5,980 & 235 & $\mathrm{X}$ & $\mathrm{X}$ & $2001-2008$ & $2003-2008$ & 2001-2008 \\
\hline
\end{tabular}


Table 1. Description of sites and period of record for types of data collected in the Fountain Creek basin, Colorado, 2001-2008.-Continued [USGS, U.S. Geological Survey; ID, identification; NAVD 88, North American Vertical Datum of 1988; ft, feet; mi², square miles; X, collected; --, not collected]

\begin{tabular}{|c|c|c|c|c|c|c|c|c|c|}
\hline $\begin{array}{l}\text { Site } \\
\text { ID }^{1}\end{array}$ & $\begin{array}{c}\text { USGS } \\
\text { station } \\
\text { number }\end{array}$ & $\begin{array}{c}\text { Station } \\
\text { name }\end{array}$ & $\begin{array}{c}\text { Elevation } \\
\text { NAVD } 88 \\
\text { (ft) }\end{array}$ & $\begin{array}{c}\text { Drainage } \\
\text { area } \\
\left(\mathbf{m i}^{2}\right)\end{array}$ & $\begin{array}{c}\text { Streamflow } \\
\text { discharge }\end{array}$ & Chemistry & Habitat & Fish $^{2}$ & $\begin{array}{c}\text { Macro- } \\
\text { invertebrate }\end{array}$ \\
\hline 16 & 07105000 & $\begin{array}{l}\text { Bear Creek near Colorado Springs, } \\
\text { Colo. }\end{array}$ & 6,520 & 6.89 & $\mathrm{X}$ & $\mathrm{X}$ & $2003-2008$ & -- & $2003-2008$ \\
\hline 17 & 384909104504401 & $\begin{array}{l}\text { Bear Creek above 8th Street at } \\
\text { Colorado Springs, Colo. }\end{array}$ & 6,037 & 9.57 & $\mathrm{X}$ & $\mathrm{X}$ & 2003-2008 & -- & 2003-2008 \\
\hline 18 & 07105500 & $\begin{array}{l}\text { Fountain Creek at Colorado Springs, } \\
\text { Colo. }\end{array}$ & 5,900 & 392 & $\mathrm{X}$ & $\mathrm{X}$ & $2001-2008$ & $2003-2008$ & $2001-2008$ \\
\hline 19 & 07105530 & $\begin{array}{c}\text { Fountain Creek below Janitell Road } \\
\text { below Colorado Springs, Colo. }\end{array}$ & 5,840 & 413 & $\mathrm{X}$ & $\mathrm{X}$ & $2001-2008$ & $2003-2008$ & $2001-2008$ \\
\hline 20 & 07105800 & Fountain Creek at Security, Colo. & 5,640 & 495 & $\mathrm{X}$ & $\mathrm{X}$ & $2001-2008$ & 2003-2008 & 2001-2008 \\
\hline 21 & 07105900 & $\begin{array}{l}\text { Jimmy Camp Creek at Fountain, } \\
\text { Colo. }\end{array}$ & 5,530 & 65.6 & $\mathrm{X}$ & $\mathrm{X}$ & 2001-2008 & $2007-2008$ & 2001-2008 \\
\hline 22 & 07106000 & Fountain Creek near Fountain, Colo. & 5,355 & 681 & $\mathrm{X}$ & $\mathrm{X}$ & $2001-2008$ & 2003-2008 & 2001-2008 \\
\hline 23 & 07106300 & Fountain Creek near Pinon, Colo. & 4,990 & 849 & $\mathrm{X}$ & $\mathrm{X}$ & $2001-2008$ & 2003-2008 & 2001-2008 \\
\hline 24 & 07106500 & Fountain Creek at Pueblo, Colo. & 4,705 & 926 & $\mathrm{X}$ & $\mathrm{X}$ & $2001-2008$ & $2003-2008$ & 2001-2008 \\
\hline
\end{tabular}

${ }^{1}$ See figure 1.

${ }^{2}$ Fish data from 07103700 were not used because community composition was restricted to one species, and fish data from 07105900 were not used because there were only 2 years of data. 
Table 2. Habitat, streamflow, and water-chemistry variables used to relate site-specific temporal patterns (seriation) in biological community structure, Fountain Creek basin, Colorado, 2001-2008.

\begin{tabular}{|c|}
\hline Variable description and unit \\
\hline Channel form \\
\hline bank height (m) \\
\hline $\begin{array}{l}\text { Froude number (current velocity divided by [ } \text { gravitational acceleration multiplied by depth of water }\} \text { exponent }{ }^{0.5} \text { ] } \\
\text { dimensionless) }\end{array}$ \\
\hline
\end{tabular}

\begin{tabular}{ll}
\hline & \multicolumn{1}{c}{ Substrate composition } \\
\hline pctSAND & $\%$ occurrence of sand from Wolman pebble count $(\%)$ \\
pctGRAVEL & $\%$ occurrence of gravel from Wolman pebble count $(\%)$ \\
pctCOBB & $\%$ occurrence of cobble from Wolman pebble count $(\%)$ \\
\hline
\end{tabular}

Streamflow

$\mathrm{MH}_{20} \quad$ Drainage area normalized annual maximum daily mean flow $\left(\mathrm{ft}^{3} / \mathrm{s} / \mathrm{mi}^{2}\right)$

FH1 ${ }^{1} \quad$ High flood-pulse count (number of events /year $\geq 75$ th percentile)

\begin{tabular}{ll}
\hline Water chemistry \\
\hline${ }^{\mathrm{DNO} 23^{1}} \quad$ dissolved nitrite plus nitrate $(\mathrm{mg} / \mathrm{L}$ as N) \\
${ }^{1}$ Variables from Zuellig and others (2007).
\end{tabular}

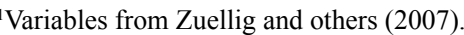

study period at cross sections in the vicinity of the USGS streamgages that had the most even distribution of streamflow. These measurements of stream discharge were used to develop site-specific stage-discharge relations (rating curves) that were then used to compute continuous discharge data from the stage record associated with the 24 USGS surface-water gages or temporary transducers. Mean daily discharge was acquired from USGS streamgage records (Crowfoot and others, 2002-2008). The Hydrologic Index Tool (HIT) software (Henriksen and others, 2006) was used to calculate annual values for normalized maximum daily mean flow (MH20) and high flood-pulse count (FH1).

Habitat. Habitat variables were measured after biological sampling each year along a predefined reach defined as 20 times the mean wetted width (range from 100 to $300 \mathrm{~m}$ [328 to $984 \mathrm{ft}]$ ). Bank height and percent riffle were estimated following the methods of Meador and others (1993) where multiple measurements were made at six equally spaced transects along the reach perpendicular to streamflow. Streambed and bank substrate were characterized from a pebble count made at approximately 100 points along the stream reach (Wolman, 1954). Although substrate was characterized into six categories during sampling, only percent sand, percent gravel, and percent cobble were considered herein (see table 2; Zuellig and others, 2007).

Water Chemistry. Routine nitrate plus nitrite samples were collected during nonstormflow (low summer flows between storms) conditions in June and September, bracketing the biological sampling using standard equipment with widthand depth-integrating techniques. All samples were collected, processed, and preserved in the field according to standard methods described in the National Field Manual by the U.S.
Geological Survey (1997-2008). Samples were analyzed at the USGS National Water Quality Laboratory (NWQL) Lakewood, Colo. See Mau and others (2007) for detailed information concerning water-chemistry collection methods, interpretation of water-chemistry data, as well as information concerning quality assurance/quality control (QA/QC). Mean concentrations were used in this analysis.

Macroinvertebrates. Macroinvertebrates were sampled annually at numerous sites during base-flow conditions (timeof-year when streamflow is dominated by groundwater seepage) in October between 2001 and 2008 (table 1). A dip-net equipped with $500-\mu \mathrm{m}$ mesh was used to collect a qualitative multihabitat sample (QMH sample type described by Moulton and others, 2000) where organisms were collected from all available habitat types within each stream reach. These samples often contained a considerable amount of debris that was reduced in the field by elutriating and sieving $(500-\mu \mathrm{m}$ mesh-metal sieve) until sample volumes were approximately $500 \mathrm{~mL}$ (about $1 \mathrm{pt}$ ). Invertebrate samples were preserved in the field with either 95-percent ethanol or 10-percent buffered formalin, and stored until delivered to the contract laboratory (Chadwick and Associates, Littleton, Colo., or Aquatic Associates, Fort Collins, Colo.). All unique taxa were identified from each sample and recorded as presence-absence data. A voucher collection was prepared and updated annually and verified by the USGS NWQL. Before analysis, macroinvertebrate taxonomic names were harmonized and ambiguities were resolved for each sample.

Fish. Fish community data were collected annually at nine sites in mid-September during base-flow conditions between 2003 and 2008 (table 1). All sites were wadable at the time of sampling and electrofished in an upstream direction 
with a single pass (Pusey and others, 1998) using two SmithRoot pulsed direct current (DC) backpack electroshockers (model 12B POW and model 15D POW). A concerted effort was made to sample all available habitats. After capture, fish were maintained in aerated live wells. Fish were identified, enumerated, and measured (total length) in the field, tallied in the nearest 2-mm (0.79-in.) length class, observed for anomalies, and released.

\section{Data Analysis}

Environmental, macroinvertebrate, and fish data were analyzed using two nonparametric multivariate routines available in the PRIMER version 6.1 software package, Plymouth, United Kingdom (Clarke and Warwick, 2001). First, the RELATE routine was applied to macroinvertebrate and fish data to determine the presence of temporal change in community structure among years. Second, at sites where temporal change occurred, the BIO-ENV routine was used to determine which subset of environmental variables (streamflow, habitat, and water chemistry) best described site-specific changes in community structure. The underlying ordination method used in these multivariate routines is nonmetric multidimensional scaling (MDS). The advantages of MDS over other ordination techniques is that MDS does not make any assumptions about the form of the data or the interrelations of the samples, and it has greater ability than other ordination methods to represent complex relations in low dimensional space. See Clarke and Warwick (2001) and Clarke and Gorley (2006) for details regarding the REALTE and BIO-ENV PRIMER routines used herein, which are briefly discussed in the sections below.

\section{Determining Site-Specific Temporal Change in Biological Communities among Years}

The RELATE routine (test for seriation) was used to estimate the degree of site-specific temporal change (Clarke and Warwick, 2001) in biological communities among years, where temporal change is defined as the extent to which community structure departs from a predefined starting point; in this case, the first year a sample was collected. The RELATE routine computes the strength between two independently derived matrices as the Spearman Rank correlation coefficient (Spearman's rho; Kendall, 1970). In this case, the two matrices were one of biological similarities and the other of temporal distances (that is, years) among samples. Under this analysis, if changes in community structure exactly match the temporal sequence (for example, community composition of the 2001 sample is most similar to 2002, less similar to 2003, and so on with 2007 being the most dissimilar), Spearman's rho (hereafter, rho) will be close to 1; whereas, it will be near zero when there is no apparent temporal pattern. In this report, rho greater than 0.9 indicates a very strong temporal change, 0.8 to 0.9 indicates a strong change, 0.7 to 0.8 indicates a relatively strong change, 0.5 to 0.7 indicates a moderate change, and less than 0.5 indicates a weak or no change. Additionally, the RELATE routine incorporates a significance test derived by permutation to test the null hypothesis of complete absence of temporal change (Clarke and Warwick, 2001). Herein, rho values were considered significant (that is, the null could not be rejected) when less than 5 percent of 999 randomly permutated rho values were greater than the real rho value ( $\mathrm{p}$ value less than 0.05). Because community change was evaluated among equally spaced temporal distances (years), the presence of a temporal change at a site (significant rho value) indicated a linear change in community structure among years.

Before the analysis, Bray-Curtis similarity values among samples were calculated from presence-absence macroinvertebrate data (Clarke and Warwick, 2001). Bray-Curtis similarity values measure the degree of similarity in community structure between pairs of samples. Values range between zero and one, where one indicates an exact match in community composition and zero indicates completely different communities between two samples. A fourth-root transformation was applied to the relative abundance fish data in order to down weight the most dominant species (that is, to prevent the similarity values calculated from these data to be driven by mostly the highly abundant species), while retaining information about rare species. The time-sequential matrix among samples was calculated directly in the RELATE routine under the "result of seriation" option in the Primer software (Clarke and Warwick, 2001).

\section{Relating Environmental Variables to Observed Temporal Change in Biological Community Structure}

At sites where temporal patterns were detected based on the RELATE test for seriation, the BIO-ENV routine was applied to determine which subset of available environmental variables best matched temporal change in biological community structure. BIO-ENV also uses rank Spearman's rho to determine the strength of association between two similarity matrices (Clarke and Warwick, 2001); in this case, between the biota and concurrently collected environmental data. All possible subsets of environmental variables were evaluated for the best match (that is, highest rho value) with the biological data; however, only models with four or fewer variables were considered to decrease spurious results. The subset with the highest rho value (closest to 1 ) for each site was determined to best describe community change among years, given the data. The significance of the best subset (Global BEST test) was calculated through permutation as described by Clarke and Gorley (2006), testing the null hypothesis of no relation between the best subset of environmental variables and the associated biota. The best subset of environmental variables was considered significant (not due to chance) when less than 5 percent of 999 randomly permutated rho values were greater than the real value $(p<0.05)$. Because the BIO-ENV analysis was specific to sites with temporal change, a significant 
BIO-ENV finding indentified the subset of selected environmental variables that best matched observed linear changes in biological community structure among years.

Before analysis, the environmental data were $\log _{10}$ transformed to improve normality and then normalized so that each variable had a mean of zero and a standard deviation of one. This normalization was necessary to ensure that each variable took on values over a similar range because different classes of environmental variables were measured on different scales. After transformation and normalization, Euclidean distance values were calculated for the environmental data (Clark and Warwick, 2001). Bray-Curtis similarity values were calculated from presence-absence macroinvertebrate data and fourth-root transformed relative abundance fish data.

\section{Temporal Change in Biological Community Structure}

Temporal change in biological community structure was defined as the extent to which community structure departed from what it was the first year a sample was collected at a site (Clarke and Warwick, 2001). The strength of departure was measured as Spearman's rho (Kendall, 1970), where rho values were close to one if strong temporal change occurred at a site and close to 0 if change was absent.

\section{Macroinvertebrate Communities}

Temporal change in macroinvertebrate community structure was present at 10 of the 24 sites evaluated (table 3 ). Of the 10 sites, only site 8 showed relatively strong temporal change ( $r h o=0.71, p<0.003)$, whereas the strength of temporal change was more moderate at the remaining 9 sites (median rho $=0.53$; range, 0.42 to 0.59 ). Sites with significant temporal change that were represented by only 6 years of macroinvertebrate data (sites 14, 16, and 21) tended to have lower rho values $(0.49,0.47$, and 0.54$)$ and higher percent significance values $(4.5,4.9$, and 4.1$)$, which is in part due to the smaller number of observations available for analysis. Additional years of data are needed to determine how genuine these directional changes in community structure are at these sites.

Although temporal change of macroinvertebrate community structure was detected among tributary and main stem sites, this change was absent at the three most downstream sites as well as at other sites (mostly tributaries) scattered throughout the basin (fig. 2). Only 6 years of data were collected at most tributary sites; therefore, additional years of data at these sites may uncover other directional changes in community structure, especially at those sites with nonsignificant rho values (closest to 0.5 ). However, it is unlikely that temporal change will be detected at the lower sites (22, 23 , and 24) by continuing to collect presence-absence type macroinvertebrate data unless major environmental changes occur at these sites; for example, changes in stream hydrology or water-quality conditions significant enough to restructure the current fauna.

\section{Fish Communities}

Significant temporal change in fish community structure was detected at five of the nine sites where fish data were analyzed (table 4). At three of the five sites, rho values were greater than 0.70 (range 0.71 to 0.76 ), indicating relatively strong temporal patterns in fish community structure between 2003 and 2008. Other temporal changes, although significant, were more moderate (rho values 0.46 to 0.51 ) at the remaining two sites.

Additional years of data are needed at sites with moderately strong rho values (around 0.5 ) to determine the persistence of temporal changes at these sites. Likewise additional years of data may reveal temporal change in community structure at site 18 (Fountain Creek at Colorado Springs) as rho was closer to 0.50 and percent significance levels were relatively low when compared to the other sites with nonsignificant rho values (sites 2, 15, and 22). In contrast to macroinvertebrates, fish community temporal changes were detected with stronger signatures and at sites distributed along the length of the Fountain Creek basin, including the two most downstream sites (fig. 3). Unfortunately, little is known about the temporal distribution of fish community structure among tributary sites as these data were not collected.

\section{Environmental Variables Correlated to Temporal Changes in Biological Community Structure}

At sites where temporal patterns were detected, additional analyses were completed to determine which subset of environmental variables best matched temporal changes in biological community structure. The strength of association between the biota and the best subset of environmental variables was measured using Spearman's rho as described by Clark and Warwick (2001).

\section{Macroinvertebrate Communities}

Environmental variables significantly described temporal change among macroinvertebrate communities at 4 of the 10 sites (sites $6,15,16$, and 20) where seriation was present (table 5). At these sites, the strength of association between the best subset of environmental variables and community structure was moderate (rho values 0.60 and 0.63 ) to strong (rho values 0.81 and 0.84 ).

The subsets of environmental variables with significant rho values appeared to be site-specific with no single variable dominating the models with the highest rho values among 
Table 3. Correlation coefficients, percent significance level, and the number of years associated with the strength of multivariate seriation of macroinvertebrate community structure among years (RELATE test for seriation).

[Sites with significant correlations between patterns in macroinvertebrate community structure and equally spaced temporal distances (years) are in bold]

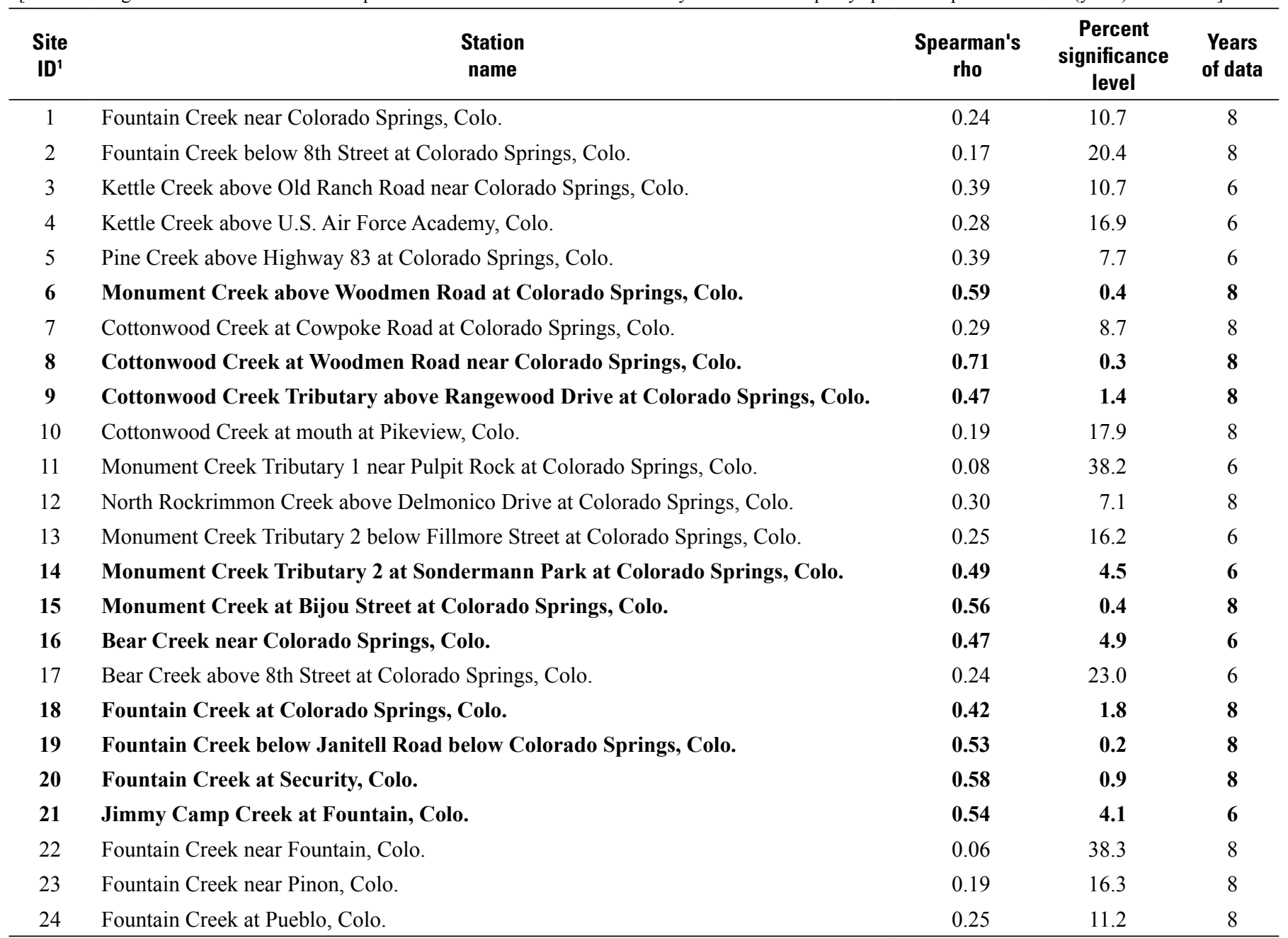

${ }^{1}$ See figure 1.

sites. For example, percent sand (pctSAND), bank height (BANKHT), and normalized annual maximum daily mean flow (MH20) best described temporal change at site 6 (Monument Creek above Woodmen Road at Colorado Springs); whereas, bank height (BANKHT) and the number of high flood-pulse counts (FH1) best described temporal change at site 16 (Bear Creek near Colorado Springs, Colo.).

Although the best subsets were not dominated by single variables, groups of similar variables were present at the four sites with significant BIO-ENV results (fig. 4). For example, substrate composition variables were present in three of the four best subsets.

Although approached differently, others have found substrate particle size to be an important indicator of macroinvertebrate community structure in the Fountain Creek basin (von Guerard, 1989; Bruce, 2002). Both the von Guerard (1989) and Bruce (2002) studies looked at macroinvertebrate and environmental data from several sites collected over a few years that were longitudinally arranged in the basin. Under such longitudinal designs (especially when inclusive of transitional areas between mountains and plains), macroinvertebrate communities are expected to change predictably along the naturally occurring environmental gradients (for example, substrate particle size decreases in a downstream direction). Integrating the results from this study with those of von Guerard (1989) and Bruce (2002) indicates that substrate characteristics of the basin, as well as site-specific changes in substrate composition over time, influenced macroinvertebrate community structure - a finding well represented in the literature (for example, see Waters, 1995). Additionally, von Guerard (1989) found that flooding 30 days prior to invertebrate sampling explained as much as 77 percent of variation in macroinvertebrate densities. Herein, three of the four best subsets of environmental variables included similar streamflow 


\section{EXPLANATION}

Stream or canal

- Sites without macroinvertebrate temporal changes

- Sites with macroinvertebrate temporal changes

23 Number corresponds to site identification numbers in table 1

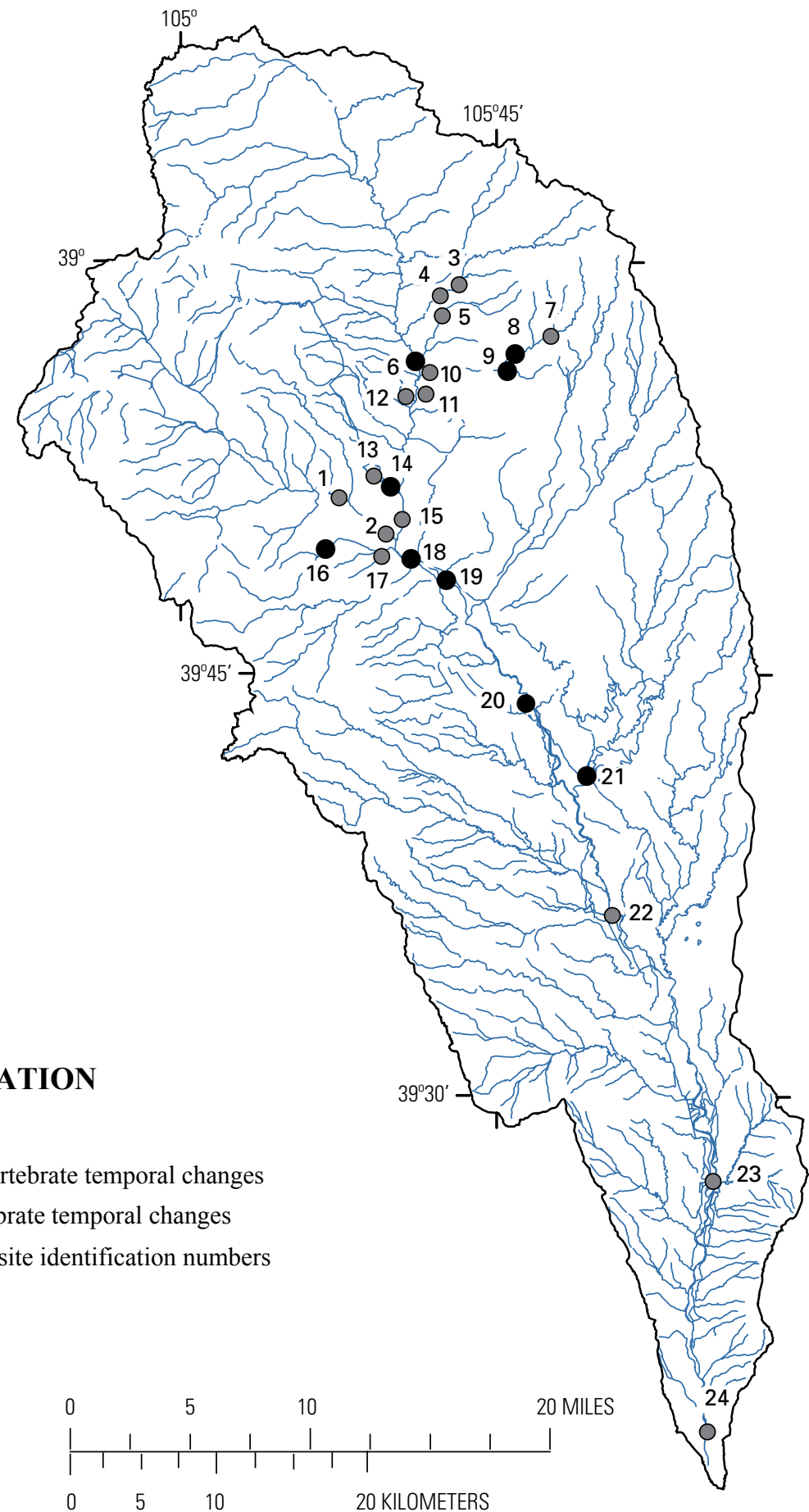

Figure 2. Spatial distribution of sites with and without temporal changes in macroinvertebrate communities among years in the Fountain Creek basin, Colorado, 2001-2008. 
Table 4. Correlation coefficients and percent significance level associated with the strength of multivariate seriation of fish communtiy structure among years (RELATE test for seriation).

[Sites with significant correlations between patterns in fish community structure and equally spaced temporal distances (years) are in bold]

\begin{tabular}{clrr}
\hline Site ID' & \multicolumn{1}{c}{ Station name } & $\begin{array}{c}\text { Spearman's } \\
\text { rho }\end{array}$ & $\begin{array}{c}\text { Percent } \\
\text { significance level }\end{array}$ \\
\hline 2 & Fountain Creek below 8th Street at Colorado Springs, Colo. & -0.19 & 72.7 \\
$\mathbf{6}$ & Monument Creek above Woodmen Road at Colorado Springs, Colo. & 0.76 & 0.6 \\
15 & Monument Creek at Bijou Street at Colorado Springs, Colo. & 0.10 & 34.4 \\
18 & Fountain Creek at Colorado Springs, Colo. & 0.36 & 9.5 \\
$\mathbf{1 9}$ & Fountain Creek below Janitell Road below Colorado Springs, Colo. & 0.76 & 0.5 \\
$\mathbf{2 0}$ & Fountain Creek at Security, Colo. & 0.71 & 0.8 \\
22 & Fountain Creek near Fountain, Colo. & -0.25 & 72.7 \\
$\mathbf{2 3}$ & Fountain Creek near Pinon, Colo. & 0.46 & 2.5 \\
$\mathbf{2 4}$ & Fountain Creek at Pueblo, Colo. & 0.51 & 3.0 \\
\hline
\end{tabular}

${ }^{1}$ See figure 1.

characteristics that were previously linked to impervious surface coverage in the Fountain Creek basin (Zuellig and others, 2007). Channel form characteristics (for example, BANKHT and pctRIF) were also included in some of the best subsets of environmental variables; however, nutrient concentrations (DNO23) were not found important among the best subsets of environmental variables (table 5, fig. 4) as was reported by Zuellig and others (2007).

Although environmental variables described temporal change in macroinvertebrate community structure at some sites (four), there were several sites (six) where temporal change was present but unexplained by the available variables (table 5, fig. 4). In most cases (sites 8, 9, 14, 18, and 19), rho values were greater than 0.4 (near moderate) and percent significance levels were weak (about 19 to 73 percent). Because the significance level of the Global BEST test in the BIO-ENV procedure is strongly related to the number of data points being fit (Clarke and Warwick, 2001), additional years of data may reveal more conclusive results, as long as the descriptive variables of temporal change in community structure are measured.

\section{Fish Communities}

Although temporal change among fish communities was detected at many sites, they were explained by environmental variables at only one site (site 6, table 6). At this site, the strength of association between the best subset of environmental variables (substrate composition-pctSAND, pctGRAVEL; channel form-BANKHT) and temporal change in fish community structure was very strong (rho 0.94 ; percent significance 0.30).

Additionally, environmental variable subset three (table 6 ; site 6 , subset 3 ) for this site was limited to pctSAND and
BANKHT, which described patterns almost equally as well $(r h o=0.90)$ as the subset with the highest rho value for that site (table 6; site 6, subset 1). These two variables (pctSAND, BANKHT) were also included in the best subset that described temporal change in macroinvertebrate community structure at this site (table 5; site 6, subset 1 ).

As with macroinvertebrate communities, there were several sites where temporal change in fish community structure was present, but these changes were not described by the environmental variables available for analysis. All fish analyses were limited to 6 years of data (2003 to 2008) at each site, which likely influenced RELATE and BIO-ENV results as described in the previous sections. Additional years of data may reveal more conclusive BIO-ENV results, if the most influential environmental variables are measured.

\section{Implications for Future Monitoring}

Results from this study were derived from a relatively small number of observations ( 6 or 8 years of data); therefore, additional years of data may reveal other sites with temporal change or possibly define stronger linkages between environmental variables and observed temporal change. Likewise the temporal changes that were detected could become weaker. Nonetheless, there were several sites where temporal changes in community structure were detected in this study that could not be explained by the selected environmental variables studied herein. At some of these sites, it is possible that the important environmental variables necessary to describe these temporal changes in aquatic communities were not available for analysis, because they were not consistently collected (see tables 5 and 6) or not part of the current study. Either way, modification of future data-collection activities is likely 


\section{EXPLANATION}

Stream or canal

- Sites without fish temporal changes

Sites with fish temporal changes

23 Number corresponds to site identification numbers in table 1

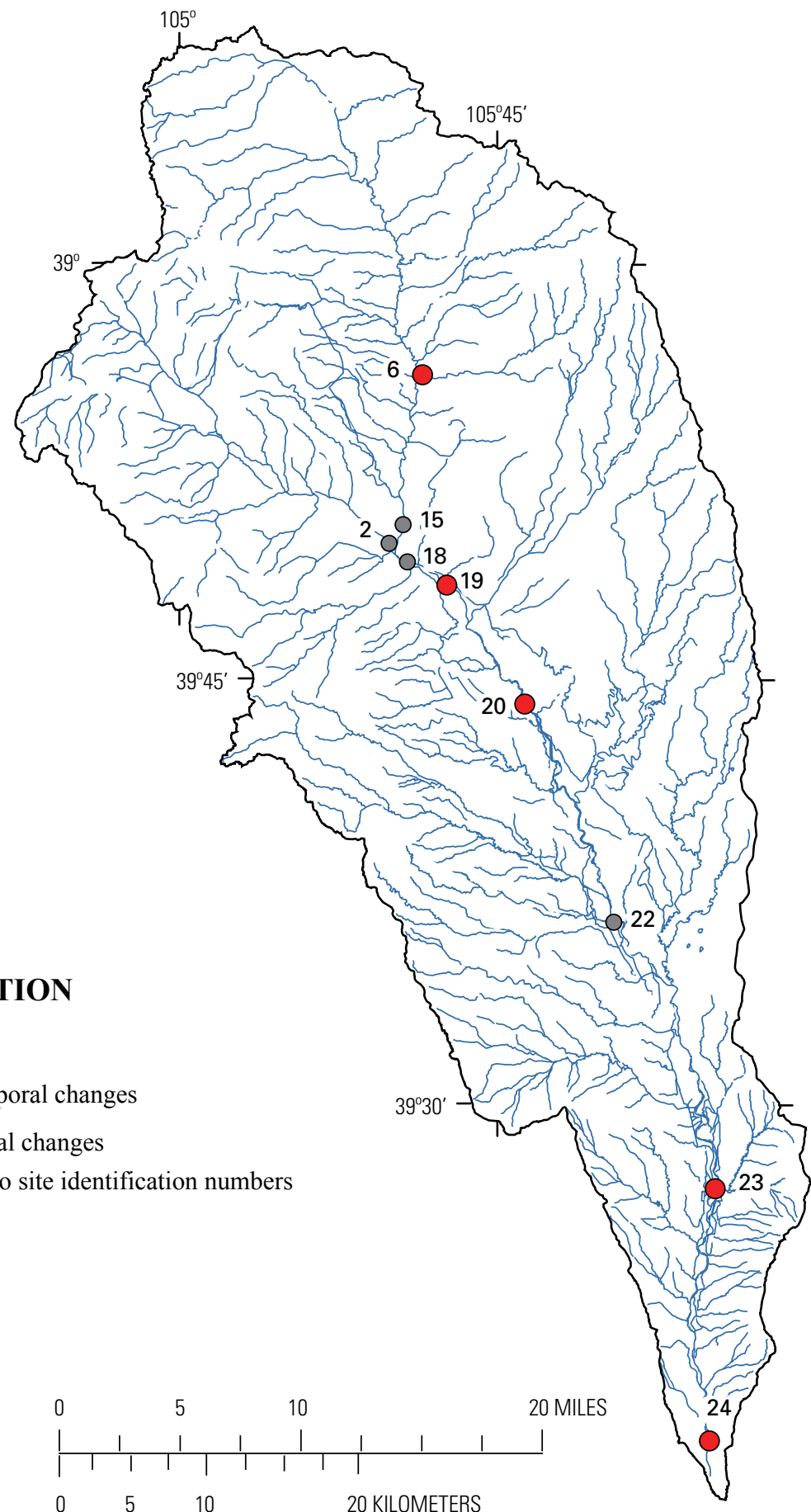

Figure 3. Spatial distribution of sites with and without temporal changes in fish communities among years in the Fountain Creek basin, Colorado, 2003-2008. 
Table 5. Results of the BIO-ENV procedure determining which environmental variables best described observed multivariate temporal change (seriation) in macroinvertebrate community structure in the Fountain Creek basin, 2001-2008.

[Three subsets for each site with the highest Spearman's rho are presented, those that were significant (that is $<5$ percent of 999 permutated rho values were greater than the real rho value) are in bold. ID, identification; \%, percent; /, per; mg/L, milligrams per liter]

\begin{tabular}{|c|c|c|c|c|c|c|c|}
\hline $\begin{array}{l}\text { Site } \\
\text { ID }^{1}\end{array}$ & Site name & $\begin{array}{l}\text { Subset } \\
\text { number }\end{array}$ & $\begin{array}{c}\text { Number } \\
\text { of } \\
\text { variables }\end{array}$ & $\begin{array}{l}\text { Spearman's } \\
\text { rho }\end{array}$ & $\begin{array}{c}\text { Percent } \\
\text { significance } \\
\text { level }\end{array}$ & $\begin{array}{l}\text { Variables included } \\
\quad \text { in model }\end{array}$ & $\begin{array}{c}\text { Variables } \\
\text { unavailable for } \\
\text { analysis }^{2}\end{array}$ \\
\hline \multirow[t]{3}{*}{6} & $\begin{array}{l}\text { Monument Creek above Woodmen Road at } \\
\text { Colorado Springs, Colo. }\end{array}$ & 1 & 3 & 0.63 & 1.3 & pctSAND, BANKHT, MH20 & none \\
\hline & & 2 & 4 & 0.62 & & pctSAND, pctCOBB, BANKHT, MH20 & \\
\hline & & 3 & 2 & 0.60 & & pctSAND, MH20 & \\
\hline \multirow[t]{3}{*}{8} & Cottonwood Creek at Woodmen Road near & 1 & 3 & 0.43 & 31.5 & pctCOBB, FROUDE, FH1 & $\mathrm{DNO} 23$ \\
\hline & & 2 & 2 & 0.42 & & pctCOBB, FROUDE, FH1 & \\
\hline & & 3 & 3 & 0.39 & & pctGRAVEL, pctCOBB, FROUDE & \\
\hline \multirow[t]{3}{*}{9} & $\begin{array}{l}\text { Cottonwood Creek tributary above Rangewood } \\
\text { Drive at Colorado Springs. Colo. }\end{array}$ & 1 & 2 & 0.45 & 19.4 & pctCOBB, FROUDE & FH1, MH20 \\
\hline & & 2 & 3 & 0.44 & & pctCOBB, FROUDE, BANKHT & \\
\hline & & 3 & 1 & 0.44 & & FROUDE & \\
\hline \multirow[t]{3}{*}{14} & $\begin{array}{l}\text { Monument Creek Tributary } 2 \text { at Sondermann } \\
\text { Park at Colorado Springs, Colo. }\end{array}$ & 1 & 2 & 0.42 & 73.2 & pctGRAVEL, pctCOBBLE & FH1, MH20 \\
\hline & & 2 & 2 & 0.35 & & pctGRAVEL, BANKHT & \\
\hline & & 3 & 3 & 0.35 & & pctSAND, pctGRAVEL, BANKHT & \\
\hline \multirow[t]{3}{*}{15} & $\begin{array}{l}\text { Monument Creek at Bijou Street at Colorado } \\
\text { Springs, Colo. }\end{array}$ & $\mathbf{1}$ & 2 & 0.60 & 3.2 & pctGRAVEL, pctCOBB & $\begin{array}{c}\text { FH1, } \\
\text { petRIF }\end{array}$ \\
\hline & & 2 & 3 & 0.58 & & pctGRAVEL, pctCOBB, FROUDE & \\
\hline & & 3 & 4 & 0.53 & & $\begin{array}{l}\text { pctGRAVEL, pctCOBB, DNO23, } \\
\text { FROUDE }\end{array}$ & \\
\hline \multirow[t]{3}{*}{16} & Bear Creek near Colorado Springs, Colo. & 1 & 2 & 0.81 & 4.2 & BANKHT, FH1 & none \\
\hline & & 2 & 3 & 0.80 & & DNO23, BANKHT, FH1 & \\
\hline & & 3 & 4 & 0.78 & & pctSAND, pctRIF, BANKHT, FH1 & \\
\hline
\end{tabular}


Table 5. Results of the BIO-ENV procedure determining which environmental variables best described observed multivariate temporal change (seriation) in

[Three subsets for each site with the highest Spearman's rho are presented, those that were significant (that is $<5$ percent of 999 permutated rho values were greater than the real rho value) are in bold. ID, identification; \%, percent; /, per; mg/L, milligrams per liter]

\begin{tabular}{|c|c|c|c|c|c|c|c|}
\hline $\begin{array}{l}\text { Site } \\
\text { ID' }\end{array}$ & Site name & $\begin{array}{l}\text { Subset } \\
\text { number }\end{array}$ & $\begin{array}{c}\text { Number } \\
\text { of } \\
\text { variables }\end{array}$ & $\begin{array}{l}\text { Spearman's } \\
\text { rho }\end{array}$ & $\begin{array}{c}\text { Percent } \\
\text { significance } \\
\text { level }\end{array}$ & $\begin{array}{l}\text { Variables included } \\
\quad \text { in model }\end{array}$ & $\begin{array}{c}\text { Variables } \\
\text { unavailable for } \\
\text { analysis }^{2}\end{array}$ \\
\hline \multirow[t]{3}{*}{18} & Fountain Creek at Colorado Springs, Colo. & 1 & 4 & 0.47 & 28.7 & pctGRAVEL, pctRIF, BANKHT & none \\
\hline & & 2 & 3 & 0.47 & & pctGRAVEL, pctCOBBLE, BANKHT & \\
\hline & & 3 & 4 & 0.44 & & $\begin{array}{l}\text { pctGRAVEL, pctCOBBLE, BANKHT, } \\
\text { MH20 }\end{array}$ & \\
\hline \multirow[t]{3}{*}{19} & $\begin{array}{l}\text { Fountain Creek below Janitell Road below } \\
\text { Colorado Springs, Colo. }\end{array}$ & 1 & 2 & 0.44 & 49.0 & DNO23, BANKHT & none \\
\hline & & 2 & 1 & 0.39 & & BANKHT & \\
\hline & & 3 & 2 & 0.35 & & pctSAND, BANKHT & \\
\hline \multirow[t]{3}{*}{20} & Fountain Creek at Security, Colo. & 1 & 4 & 0.84 & 0.9 & pctSAND, pctRIF, FH1, MH20 & none \\
\hline & & 2 & 4 & 0.82 & & pctSAND, pctCOBB, FH1, MH20 & \\
\hline & & 3 & 3 & 0.80 & & pctSAND, FH1, MH20 & \\
\hline \multirow[t]{3}{*}{21} & Jimmy Camp Creek at Fountain, Colo. & 1 & 1 & 0.10 & 90.1 & pctGRAVEL & pctCOBBLE, pctRIF \\
\hline & & 2 & 2 & 0.08 & & pctSAND MH20 & \\
\hline & & 3 & 4 & 0.02 & & $\begin{array}{l}\text { pctSAND, pctGRAVEL, BANKHT, } \\
\text { MH20 }\end{array}$ & \\
\hline
\end{tabular}

${ }^{1}$ See figure 1.

${ }^{2}$ pctSAND, \% occurrence of sand from Wolman pebble count (Wolman, 1954); BANKHT, bank height; MH20, drainage area normalized annual maximum daily mean flow; pctCOBB, \% occurrence of cobble from Wolman pebble count; FH1, high flood-pulse count (number of events per year with flows above the 75th percentile); FROUDE, (Froude number, current velocity divided by [ gravitational acceleration multiplied by depth of water exponent ${ }^{0.5}$ ] dimensionless); DNO23, dissolved nitrite plus nitrate (mg/L as N); pctGRAVEL, \% occurrence of gravel from Wolman pebble count; pctRIF, \% of reach composed of riffle habitat. 
07103970-Monument Creek above Woodmen Rd. at Colorado Springs, Colo.

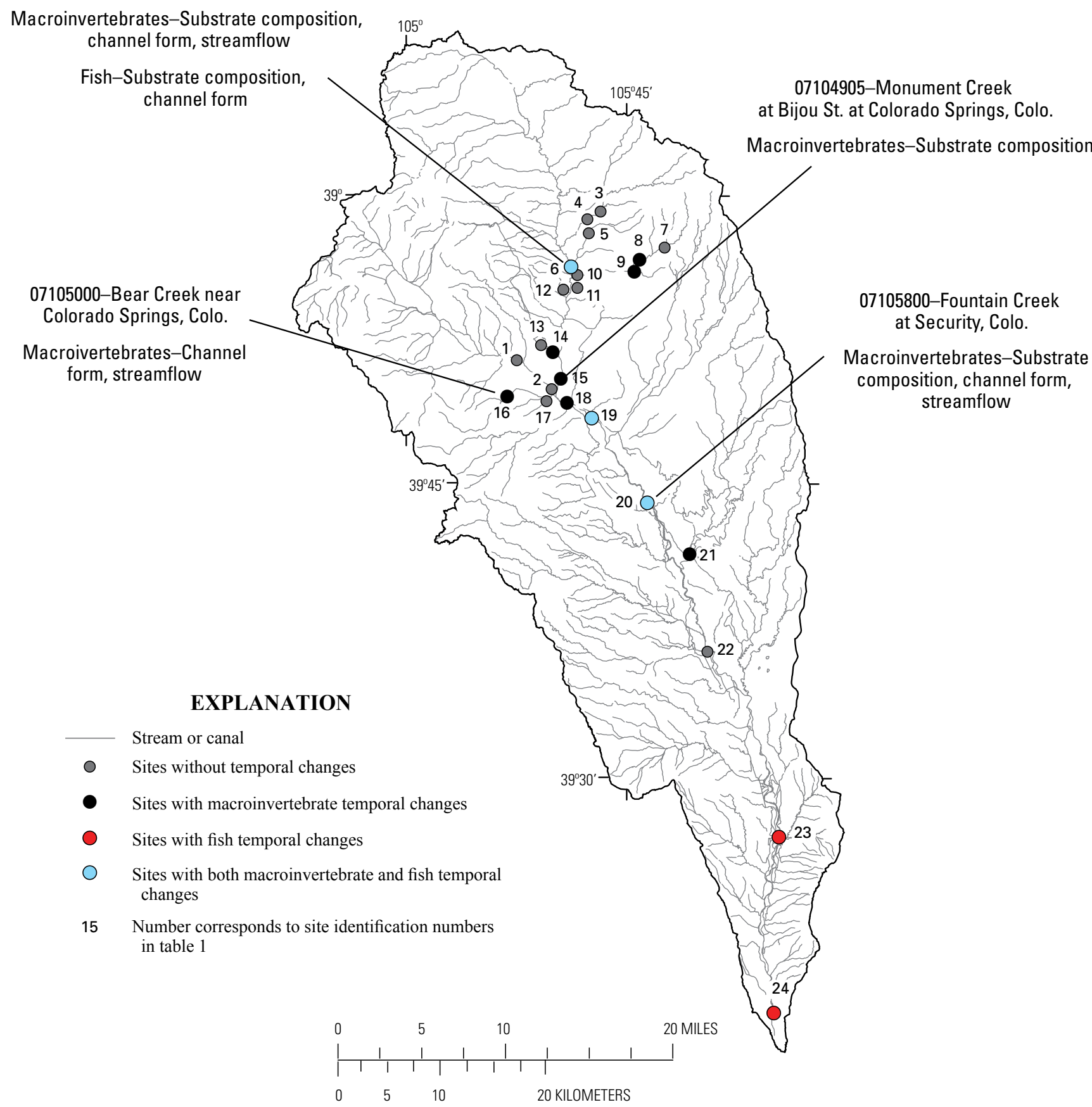

Figure 4. Spatial distribution of sites with and without temporal changes in fish (2003-2008) and macroinvertebrate (2001-2008) communities among years in the Fountain Creek basin, Colorado. 
Table 6. Results of the BIO-ENV procedure determining which environmental variables best described observed multivariate temporal change (serial) in fish community structure in the Fountain Creek basin, 2003-2008.

[Three subsets for each site with the highest Spearman's rho are present, those that were significant (that is, $<5$ percent of 999 permutated rho values greater than observed rho value) are in bold. ID, identification; \%, percent; /, per; mg/L, milligrams per liter]

\begin{tabular}{|c|c|c|c|c|c|c|c|}
\hline $\begin{array}{l}\text { Site } \\
\text { ID }^{1}\end{array}$ & Site name & $\begin{array}{l}\text { Subset } \\
\text { number }\end{array}$ & $\begin{array}{c}\text { Number } \\
\text { of } \\
\text { variables }\end{array}$ & $\begin{array}{l}\text { Spearman's } \\
\text { rho }\end{array}$ & $\begin{array}{c}\text { Percent } \\
\text { significance } \\
\text { level }\end{array}$ & $\begin{array}{l}\text { Variables } \\
\text { included } \\
\text { in model }^{2}\end{array}$ & $\begin{array}{c}\text { Variables } \\
\text { unavailable } \\
\text { for analysis }{ }^{2}\end{array}$ \\
\hline \multirow[t]{3}{*}{6} & Monument Creek above Woodmen Road at Colorado & 1 & 3 & 0.94 & $\mathbf{0 . 3 0}$ & pctSAND, pctGRAVEL, BANKHT & none \\
\hline & & 2 & 4 & 0.92 & & $\begin{array}{l}\text { pctSAND, pctGRAVEL, DNO23, } \\
\text { BANKHT }\end{array}$ & \\
\hline & & 3 & 2 & 0.90 & & pctSAND, BANKHT & \\
\hline \multirow[t]{3}{*}{19} & $\begin{array}{l}\text { Fountain Creek below Janitell Road below Colorado } \\
\text { Springs, Colo. }\end{array}$ & 1 & 1 & 0.72 & 25.20 & pctRIF & none \\
\hline & & 2 & 3 & 0.70 & & pctGRAVEL, pctCOBB, pctRIF & \\
\hline & & 3 & 4 & 0.69 & & pctGRAVEL, DNO23, pctRIF, FH1 & \\
\hline \multirow[t]{3}{*}{20} & Fountain Creek at Security, Colo. & 1 & 1 & 0.72 & 28.40 & pctCOBB & none \\
\hline & & 2 & 2 & 0.70 & & pctCOBB, DNO23 & \\
\hline & & 3 & 4 & 0.70 & & pctCOBB, DNO23, BANKHT, FH1 & \\
\hline \multirow[t]{3}{*}{23} & Fountain Creek near Pinon, Colo. & 1 & 3 & 0.66 & 27.10 & pctSAND, pctGRAVEL, MH20 & pctRIF \\
\hline & & 2 & 3 & 0.58 & & pctGRAVEL, BANKHT, MH20 & \\
\hline & & 3 & 2 & 0.58 & & pctGRAVEL, MH20 & \\
\hline \multirow[t]{3}{*}{24} & Fountain Creek at Pueblo, Colo. & 1 & 3 & 0.57 & 49.10 & pctSAND, DNO23, FROUDE & pctCOBB, pctRIF \\
\hline & & 2 & 2 & 0.50 & & DNO23, FROUDE & \\
\hline & & 3 & 4 & 0.50 & & $\begin{array}{l}\text { pctSAND, DNO23, FROUDE, } \\
\text { BANKHT }\end{array}$ & \\
\hline
\end{tabular}

${ }^{1}$ See figure 1.

${ }^{2}$ pctSAND, \% occurrence of sand from Wolman pebble count (Wolman, 1954); pctGRAVEL, \% occurrence of gravel from Wolman pebble count; BANKHT, bank height; DNO23, dissolved nitrite plus nitrate (mg/L as N); pctRIF, \% of reach composed of riffle habitat; pctCOBB, \% occurrence of cobble from Wolman pebble count; FH1, high flood pulse count (number of events per year with flows above the 75th percentile); MH20, drainage are normalized annaul maximum daily mean flow; FROUDE, (Froude number, current velocity divided by [\{gravitational acceleration multiplied by depth of water\} exponent0.5] dimensionless). 
necessary to better understand site-specific relations between biological communities and selected environmental variables. Previous biological studies in the Fountain Creek basin were observational in nature. Although these studies have done well at characterizing the environment and biology, they have difficulty linking human-induced environmental alterations to changes in aquatic community structure. To develop causal linkages between individual stressors and changes in aquatic communities in the Fountain Creek basin, it will be necessary to conduct observational studies (such as this one) along with field and laboratory experiments (Clements and others, 2002). Information generated from such integrative studies are powerful for developing causal relations and may be imperative for well-targeted mitigation and/or management efforts in the Fountain Creek basin.

\section{Summary and Conclusions}

Fountain and Monument Creeks (hereafter, Fountain Creek basin) drain approximately $926 \mathrm{mi}^{2}$ of the eastern slope of the Rocky Mountains in south-central Colorado. In 2001, the U.S. Geological Survey, in cooperation with Colorado Springs City Engineering, began a study to better understand the relations between environmental characteristics and biological communities in the Fountain Creek basin in order to aid water-resource management and guide future monitoring activities. Environmental (streamflow, habitat, and water chemistry) and biological (fish and macroinvertebrates) data were collected annually at 24 sites between 2001 and 2008 (fish data collected 2003-2008 only). For this report, these data were first analyzed to determine the presence of temporal change in macroinvertebrate and fish community structure among years using nonparametric multivariate statistics (RELATE, PRIMER ver. 6.1, Plymouth, United Kingdom). Where temporal change in the biological communities was found, these data were further analyzed using additional nonparametric multivariate techniques to determine which subset of selected streamflow, habitat, or water chemistry variables best described site-specific changes in community structure relative to a gradient of urbanization (BIO-ENV, PRIMER ver. 6.1, Plymouth, United Kingdom).

This study found the presence of temporal change in community structure at 10 sites for macroinvertebrates and 5 sites for fish in the Fountain Creek basin. Of these sites, environmental variables significantly described temporal change among macroinvertebrate communities at four sites (Monument Creek above Woodmen Road at Colorado Springs, Colo.; Monument Creek at Bijou Street at Colorado Springs, Colo.; Bear Creek near Colorado Springs, Colo.; Fountain Creek at Security, Colo.) and at one site for fish (Monument Creek above Woodmen Road at Colorado Springs, Colo.). Combinations of environmental variables describing directional temporal change in the biota appeared to be site specific as no single variable dominated the results; however, substrate composition variables (percent substrate composition composed of sand, gravel, or cobble) collectively were present in almost 80 percent of the environmental variable subsets that were significantly correlated with temporal change in the macroinvertebrate and fish community structure. Other important environmental variables related to temporal change in the biological community structure included those describing channel form (streambank height) and streamflow (normalized annual mean daily flow, high flood-pulse count).

Site-specific results from this study were derived from a relatively small number of observations (6 or 8 years of data). Additional years of monitoring data will likely improve statistical interpretations and provide more insight into the observations described in this report. There were several sites where temporal change was detected in this study that could not be explained by the selected environmental variables studied herein. Modification of current data-collection activities is necessary to better understand site-specific relations between biological communities and environmental variables.

\section{Acknowledgments}

Gary Dowler, Paul Foutz, Dan Frankowski, Londell Ackley, and Harry Crockett of the Colorado Division of Wildlife (CDOW) provided backpack electrofishing equipment and contributed greatly to the fish-sampling efforts. Thanks to Lisa Ross, Colorado Springs City Engineering, for her support of the program. Thanks also to Colorado Springs Utilities for their support. Harry Crockett and Travis Schmidt (USGS) provided thoughtful reviews and comments that improved the report. The authors also thank the USGS hydrographers that collected, compiled, and analyzed streamflow measurement data.

\section{References Cited}

Bruce, J.F., 2002, Characterization and analysis of temporal and spatial variations in habitat and macroinvertebrate community structure, Fountain Creek basin, Colorado Springs and vicinity, Colorado, 1998-2001: U.S. Geological Survey Water-Resources Investigations Report 02-4093, 28 p.

Clarke, K.R., and Gorley, R.N., 2006, Primer version 6-User manual/tutorial, Primer-E: Plymouth, United Kingdom, $190 \mathrm{p}$.

Clarke, K.R., and Warwick, R.M., 2001, Change in marine communities-An approach to statistical analysis and interpretation (1st ed.): Plymouth, United Kingdom, Plymouth Marine Laboratory, $172 \mathrm{p}$. 
Clements, W.H., Carlisle, D.M., Courtney, L.A., and Harrahy, E.A., 2002, Integrating observational and experimental approaches to demonstrate causation in stream biomonitoring studies: Environmental Toxicology and Chemistry, v. 21 , p. $1138-1146$.

Crowfoot, R.M., Steger, R.D., Payne, W.F., and O'Neill, G.B., 2002, Water resources data, Colorado, water year 2001, v. 1: U.S. Geological Survey Water-Data Report CO 01-1, 539 p.

Crowfoot, R.M., Payne, W.F., and O’Neill, G.B., 2003, Water resources data, Colorado, water year 2002, v. 1: U.S. Geological Survey Water-Data Report CO 02-1, 609 p.

Crowfoot, R.M., Boulger, R.W., Payne, W.F., and O’Neill, G.B., 2004, Water resources data, Colorado, water year 2003, v. 1: U.S. Geological Survey Water-Data Report CO 03-01, 577 p.

Crowfoot, R.M., Payne, W.F., O’Neill, G.B., and Boulger, R.W., 2005, Water resources data, Colorado, water year 2004, v. 1: U.S. Geological Survey Water-Data Report CO 04-01, 344 p.

Crowfoot, R.M., Payne, W.F., O’Neill, G.B., Boulger, R.W., and Sullivan, J.R., 2005, Water resources data, Colorado, water year 2005, accessed March 2008, available online at http://wdr.water.usgs.gov.

Crowfoot, R.M., Payne, W.F., O’Neill, G.B., Boulger, R.W., Sullivan, J.R., and Lewis, M.E., 2006, Water resources data, Colorado, water year 2006, accessed March 2008, available online at http://wdr.water.usgs.gov.

Crowfoot, R.M., Payne, W.F., O’Neill, G.B., Sullivan, J.R., and Lewis, M.E., 2007, Water resources data, Colorado, water year 2007, accessed March 2008, available online at http://wdr.water.usgs.gov.

Crowfoot, R.M., Payne, W.F., O’Neill, G.B., Sullivan, J.R., Smith, G.J., and Lewis, M. E., 2008, Water resources data, Colorado, water year 2008, accessed January 15, 2008, available online at http://wdr.water.usgs.gov.

Edelmann, P., Ferguson, S.A., Stogner, R.W., Sr., August, M., Payne, W.F., and Bruce, J.F., 2002, Evaluation of water quality, suspended sediment, and stream morphology with an emphasis on effects of storm flow on Fountain and Monument Creek basins, Colorado Springs and vicinity, Colorado, 1981 through 2001: U.S. Geological Survey Water-Resources Investigations Report 02-4104, 59 p.

Hansen, W.R., and Crosby, E.J., 1982, Environmental geology of the Front Range urban corridor and vicinity, Colorado, with a specific section on Physical properties and performance characteristics of surficial deposits and rock units in the greater Denver area by R.R. Shroba: U.S. Geological Survey Professional Paper 1230, 99 p.
Henriksen, J.A., Heasley, J., Kennen, J.G., and Nieswand, S., 2006, Users' manual for the hydroecological integrity assessment process software (including the New Jersey assessment tools), Fort Collins, Colo.: U.S. Geological Survey Open-File Report 2006-1093, 71p.

Kendall, M.G., 1970, Rank correlation methods (4th ed.): Griffin, London, 166 p.

Larsen, L.S., 1981, Soil survey of El Paso County area, Colorado: Washington, D.C., U.S. Department of Agriculture, Soil Conservation Service, 212 p.

Mau, D.P., Stogner, R.W., Sr., and Edelman, Patrick, 2007, Characterization of stormflows and wastewater treatmentplant effluent discharges on water quality, suspended sediment, and channel morphology for Monument and Fountain Creek watersheds, Colorado, 1981-2006: U.S. Geological Survey Scientific Investigations Report 07-5104, 76 p.

Meador, M.R., Hupp, C.R., Cuffney, T.F., and Gurtz, M.E., 1993, Methods for characterizing stream habitat as part of the National Water-Quality Assessment Program: U.S. Geological Survey Open-File Report 93-408, 48 p.

Moulton, S.R., II, Carter, J.L., Grotheer, S.A., Cuffney, T.F., and Short, T.M., 2000, Methods of analysis by the U.S. Geological Survey National Water-Quality LaboratoryProcessing, taxonomy, and quality control of invertebrate samples: U.S. Geological Survey Open-File Report 00-212, $49 \mathrm{p}$.

Omernik, J.M., 1987, Ecoregions of the conterminous United States: Annals of the Association of American Geographers, v. 77, p. 118-125.

Pusey, B.J., Kennard, M.J., Arthur, J.M., and Arthington, A.H., 1998, Quantitative sampling of stream fish assemblages: Single- vs. multiple-pass electrofishing: Australian Journal of Ecology, v. 23, p. 365-374.

Rantz, S.E., and others, 1982, Measurement and computation of streamflow_-Volume 2, Computation of discharge: U.S. Geological Survey Water-Supply Paper 2175, 347 p.

Stogner, R.W., Sr., 2000, Trends in precipitation and streamflow and changes in stream morphology in the Fountain Creek watershed, Colorado, 1939-99: U.S. Geological Survey Water-Resources Investigations Report 00-4130, $43 \mathrm{p}$.

U.S. Geological Survey, 1997-2008, National field manual for the collection of water-quality data: U.S. Geological Survey Techniques of Water-Resources Investigations, book 9, chaps. A1-A9, available online at http://pubs.water.usgs. gov/twri9A.

von Guerard, Paul, 1989, Sediment-transport characteristics and effects of sediment transport on benthic invertebrates in the Fountain Creek drainage basin upstream from Widefield, southeastern Colorado, 1985-88: U.S. Geological Survey Water-Resources Investigations Report 89-4161, 133 p. 
Waters, T.F., 1995, Sediment in streams-Sources, biological effects, and control: American Fisheries Society Monograph 7, $249 \mathrm{p}$.

Wolman, M.G., 1954, A method for sampling coarse riverbed material: Transactions of the American Geophysical Union, v. 35 , p. $951-956$.

Zuellig, R.E., Bruce, J.F., Evans, E.E., and Stogner, R.W., 2007, Urban-related environmental variables and their relation with patterns in biological community structure in the Fountain Creek basin, Colorado, 2003-2005: U.S. Geological Survey Scientific Investigations Report 2007-5225, 24 p.
Publishing support provided by:

Denver Publishing Service Center

For more information concerning this publication, contact: Director, USGS Colorado Water Science Center Box 25046, Mail Stop 415

Denver, CO 80225

(303) 236-4882

Or visit the Colorado Water Science Center Web site at: http://co.water.usgs.gov/ 
